\title{
Empathy Levels and Personal Meaning Profiles of Psychological Counselor Candidates: A Longitudinal Study
}

\section{Psikolojik Danışman Adaylarının Empati Düzeyleri ve Kişisel Anlam Profilleri: Boylamsal Bir Çalışma}

\author{
Betül DÜşÜNCELI* (D) Tuğba Seda ÇOLAK** (D) Mustafa KOÇ***iD
}

Received: 02 December 2021

Research Article

Accepted: 08 June 2021

ABSTRACT: The aim of this longitudinal study was to examine the empathy levels and personal meaning profiles of the psychological counseling candidates studying at university. The research was based on descriptive method. The main purpose was to comparatively examine the changes in the empathy levels and personal meaning profiles of the participants with respect to years. The study group consisted of 36 participants (30.6\% of whom were boys, and $69.4 \%$ of whom were girls) who were studying at university between the academic years of 2015 and 2019 . The data were collected once each year (first, second, third, and fourth grades) from the participants involved in the study group. In order to collect data, which were then analyzed using Statistical Package (SPSS), One Way Anova with repeated measures and the Friedman Test were used. The findings revealed that the basic empathy levels of the prospective psychological counselors did not change during their undergraduate studies, whereas the level of their pursuit of personal meaning in religion and intimacy did change. Counselor Candidates received the highest score in the first year and the lowest score in the fourth year on the dimensions of religion and intimacy of the Personal Meaning Profile scale.

Keywords: Empathy, meaning, longitudinal screening, psychological counseling.

ÖZ: $\mathrm{Bu}$ araştırmanın amacı, üniversitede öğrenim görmekte olan psikolojik danışman adaylarının empati düzeyleri ve kişisel anlam profillerinin boylamsal olarak incelenmesidir. Araştırma betimsel yöntemle gerçekleştirilmiştir. Temel amaç psikolojik danışman adaylarının empati düzeyleri ve kişisel anlam profillerinin yıllara göre değişimini karşılaştırmalı olarak incelemektir. Araştırmanın çalışma grubunu 2015-2019 eğitim öğretim yılları arasında dört yıl boyunca öğrenim gören, çalışmaya gönüllü olarak katılım sağlayan 36 psikolojik danışman adayı (\%30.6's1 erkek, 69.4'ü kız) oluşturmaktadır. Araştırmanın verileri çalışma grubunda yer alan katılımcılardan öğrenim gördükleri her eğitim yılında (birinci, ikinci, üçüncü ve dördüncü sınıf) toplamda dört kez toplanmıştır. Araştırmanın verileri Temel Empati Ölçeği ve Kişisel Anlam Profili ile toplanmıştır. Veriler SPSS paket programı ile analiz edilmiştir. Verilerin çözümlenmesinde tekrarlı ölçümler için Tek Yönlü Varyans Analizi ve Friedman testi uygulanmıştır. Araştırma sonucunda, psikolojik danışman adaylarının temel empati düzeylerinin lisans eğitimleri süresince değişim göstermediği, kişisel anlamı dinde arama ve yakınlıkta arama düzeylerinin ise lisans eğitimleri süresince değişim gösterdiği bulunmuştur. Psikolojik danışman adayları, Kişisel Anlam Profili ölçeğinin din ve yakınlık boyutlarına ait en yüksek puanı birinci sınıfta, en düşük puanı dördüncü sınıfta almışlardır.

Anahtar kelimeler: Empati, anlam, boylamsal tarama, psikolojik danışmanlık.

\footnotetext{
* Corresponding Author: Asst. Prof. Dr., Sakarya University, Sakarya, Turkey, bbayraktar@sakarya.edu.tr, https://orcid.org/0000-0002-6794-8811

** Assoc. Prof. Dr., Düzce University, Düzce, Turkey, tugbacolak@duzce.edu.tr, https://orcid.org/0000-0002-72191999

*** Prof. Dr., Düzce University, Düzce, Turkey, mustafa.koc@ duzce.edu.tr, https://orcid.org/0000-0002-8644-4109
}

\section{Citation Information}

Düşünceli, B., Çolak, T. S., \& Koç, M. (2021). Empathy levels and personal meaning profiles of psychological counselor candidates: A longitudinal study. Kuramsal Eğitimbilim Dergisi [Journal of Theoretical Educational Science], 14(3), 373-388. 
Psychological counseling and guidance is a profession that aims to offer help to people (Eryılmaz \& Mutlu Süral, 2014). The qualifications of the individuals who will perform this profession, which serves a universal purpose, and the adequacy of their education are important in terms of the quality of the service to be provided in mental health. Rogers (1957) states that the counseling relationship established between the client and the counselor is both necessary and sufficient for constructive changes in the client and attributes a great deal of value to this relationship. In the counseling process, the most meaningful theme for both clients and counselors is the counseling relationship (Sackett et al., 2012). The desire to be understood in therapy interviews is at the top of the list for clients (Egan, 2011). Accordingly, it is possible to say that the relationship between the client and the counselor has therapeutic power. The effective use and development of this power are among the issues that researchers examine.

In the counseling process, counselors use various therapeutic skills such as active listening, reflection, and empathy. These therapeutic skills strengthen the relationship between the client and the counselor (Nelson-Jones, 2015). Counselors listen to their clients to understand them and their problems and respond to them in constructive ways (Egan, 2011). Ensuring the necessary conditions in the process will encourage the client to participate in the process and increase the counselor's selfesteem (Hackney \& Cormier, 2008). To provide these conditions, psychological counselor training is important.

Psychological counseling is a field that requires theoretical knowledge as well as field-specific skills (Kurtyılmaz, 2015). Many researchers emphasize empathy when responding to the question "What are the characteristics of an effective psychological counselor?" (Combs, 1986; Egan, 2011; Rogers, 1957). Empathy is generally defined as a person's correct understanding of their feelings, needs, and thoughts by putting themselves in place of the other people (Dökmen, 2006; Egan, 2011). In terms of psychological counseling process, it can be defined as the capacity of a counselor to mentally identify themselves with the client to understand the client's inner world (Nelson-Jones, 2015). Empathy is regarded as a skill that can be developed through training (Karaca et al., 2013; Sargın, 1993; Yüksel, 2004). To feel empathy for a person does not mean to have the same feelings and thoughts that the other person has (Dökmen, 2006). Sayar (2011) refers to empathy as "the other within oneself" with a more metaphorical description and describes it as the great meeting where the beings flow into each other, but still, each entity remains separately.

The courses offered to psychological counselor candidates in Turkey within the scope of counselor training such as 'principles and techniques of counseling' and 'individual counseling skills' include theories and practices which aim at developing empathy skills. The psychological counselor's ability to give an advanced level of empathic response is possible with effective use of content and emotion reflection skills. Understanding what the client is saying and communicating with them are the main features expected from psychological counselors (Gladstein, 1983; Voltan-Acar, 2015). Empathic understanding plays a crucial role in establishing a therapeutic relationship (Erdur-Baker, 2016). The level of demonstrating or developing this skill in psychological counseling and guidance has been the subject of many studies (Alver, 2005; Combs, 1986; Egan, 2011; Sargın, 1993; Uslu, 2005). However, no longitudinal study that examined whether the empathy levels of psychological counselor candidates 
changed during their undergraduate studies was found. It is believed that this study will help fill this gap in the literature. In this context, this study aims to examine the current educational status of psychological counselor candidates developmentally and contribute to the process of structuring psychological counseling education.

Another aspect of the study is the personal meanings of the psychological counselor candidates. People keep looking for answers to many existential questions like "What is the meaning of life?", "What is my purpose in this life?", "Why are we here?" or "What am I struggling for?" throughout their lives (Batthyany \& RussoNetzer, 2014). According to Frankl, one can find meaning in life in three different ways, which he lists as:

1. Creating a work or doing a work (creative values),

2. Experiencing something or interacting with a person (experiential values),

3. Developing an attitude towards unavoidable suffering (attitudinal values) (Frankl, 2007).

Wong (1998) further expanded these three ways suggested by Frankl in his scale of Personal Meaning Profile and examined the meaning experienced by the individual with seven factors: intimacy, achievement, relationship, religion, self-transcendence, self-acceptance, and perceived justice. The sources of meaning cover many different levels of needs, from physiological needs to transcendental and spiritual needs (Mcdonald et al., 2012). As social creatures, human beings can get help from someone else while meeting these needs. In this direction, Logotherapy, known for its existentialist origin, puts forward the "therapy through meaning" argument (Frankl, 1999). This indicates that individuals can find meaning in their lives and recover.

Although counselors have a role in leading others (clients) to find meaning in their lives, it can be said that it is important for them to find meaning in their own lives. Being able to stay fit and stay away from burnout is an important point in occupations with a high level of interaction with the group s/he works as counselor and therapist (Skovholt \& Trotter-Mathison, 2011). This makes the psychological counselor's personal life related to their counseling skills. Life satisfaction of psychological counselors who find meaning in their lives increases (Degges-White \& Stoltz, 2015). Consequently, the well-being of the counselors also affects the level of meeting the needs of their clients. (Lawson, 2007). It is thought that psychological counselors who take healthy steps in their pursuit of personal meaning will contribute to the meaning worlds of their clients.

Considering a positive relationship between empathy and the meaning of life (Damiano et al., 2017), both variables were considered together in this study. Wong (2012), who has many works on the meaning of life, states that "empathy can also be developed by recognizing the universality of existential concerns and human problems." In this context, depending on whether the psychological counselors' search for the meaning of life in a personal sense changed with the empathy skills, they will demonstrate in the professional sense formed a basis for this study.

It can be said that if psychological counselor candidates' can realize the meaning of their own lives, this will contribute to their psychological counseling skills. The undergraduate education that psychological counselors receive to develop these skills also corresponds to a period representing the transition from adolescence to adulthood. 
In other words, it is possible to say that in this period, counselor candidates' inquiries about the meaning in their lives were intense. Starting from this point, this study aims to examine and compare the changes in the empathy levels and personal meaning profiles of psychological counselor candidates during their undergraduate studies year by year.

In line with the purpose, answers to the following questions have been sought in this study:

1. Do the empathy levels of psychological counselor candidates change during their undergraduate studies?

2. Do the personal meaning profiles of psychological counselor candidates change during their undergraduate studies?

\section{Method}

\section{Research Design}

The research was conducted using the longitudinal screening model. Longitudinal screening studies involve repeated measurements of a variable at different times, and it is done to examine time-dependent changes in individuals (Fraenkel \& Wallen, 2006). The data were collected from the psychological counselor candidates periodically in the first, second, third, and fourth grades (four times in total).

\section{Study Group}

This study was initiated in the spring semester of the 2015-2016 academic year by performing the first application to 70 students enrolled in the first grade of the Faculty of Education guidance and psychological counseling program at a public university in Turkey. The students were informed that their names and surnames would be recorded to keep track of their development throughout four years, and those who volunteered to participate were involved in the study. The data were obtained from the same participants in every spring semester during 2015-2019 academic years. In the spring semester of 2018-2019 academic year, it was found out that 11 of these students had graduated, two had ended their studies at their request, and two had been transferred to other universities. In addition, 19 students could not be reached when the data for repeated measures were collected. Therefore, the study was completed with 36 psychological counseling candidates, 11 of whom were boys (30.6\%) and 25 of whom were girls $(69.4 \%)$, who took part in the study throughout four years. The ages of the participants ranged from 23 to 31 by the spring semester of 2018-2019 academic year.

\section{Data Collection Tools}

Two different data collection tools were used in the study. These were the Basic Empathy Scale and the Personal Meaning Profile Scale. Detailed information about each is given below.

\section{The Basic Empathy Scale}

Jolliffe and Farrington originally developed the scale in 2006, and it was adapted to Turkish by Topcu et al. in 2010. The Basic Empathy Scale is a five-point Likert-type (1=Strongly Disagree, 2=Disagree, 3=Neither Agree, nor Disagree, 4=Agree, $5=$ Strongly Agree) scale consisting of 20 items in total. Eight negatively worded items 
(reversed items) are reverse-scored. To obtain a total score, all items were collected. It was observed that the fit indices (GFI=.90, AGFI=.87, RMSEA=.06) obtained as a result of the scale were adequate. The Cronbach Alpha coefficient of the scale, whose psychometric properties were found sufficient in the Turkish adaptation study, was measured between the range of .76 -.80 (Topcu et al., 2010). Some sample items related to the scale are as follows: "My friend's emotions don't affect me much," "I don't feel sorry when I see other people crying."

\section{Personal Meaning Profile}

The original scale, which was a seven-point Likert-type scale ("1" Not at all; "7" quite a lot) which included 57 items, was developed by Wong (1998). There are no reverse-scored items on the scale. According to this scale, the more the number of subscales with a high score is, the greater gives information about the widening of personal meaning in life. The scale provides information on how close an individual is to ideal perception of personal meaning by showing the specific areas in which s/he is seeking for and experiencing meaning (Wong, 1998).

Akin et al. carried out the adaptation of the scale into Turkish in 2016. In a study conducted with 304 university students, as a result of confirmatory factor analysis, it was found that the fit indexes obtained from the scale consisting of 57 items and seven factors (achievement, relationship, religion, intimacy, self-transcendence, selfacceptance, and perceived justice) were acceptable ( $x^{2}=3170.41, s d=1518, p=.00, x^{2} /$ $s d=2.08$, RMSEA=.060, NFI=.87, NNFI=.92, CFI=.93, IFI=.93, SRMR=.07). Personal Meaning Profile, the factor loads of the Turkish form, are between .30 and .69. The Cronbach Alpha coefficient of the scale was measured as .93. Therefore, the Turkish version of the scale can be said to be a reliable and valid measurement tool (Akin et al., 2016).

\section{Data Analysis}

While analyzing the data collected to determine whether psychological counselor candidates' empathy levels changed during their four-year undergraduate studies, One Way Anova for repeated measures was utilized. To perform One Way Anova for repeated measurements, it is necessary to examine the assumptions of normality and sphericity (Can, 2013). For the assumption of normality, the ShapiroWilk test was used because the number of participants was fewer than 50. It was observed that the psychological counselor candidates' first-year, third-year, and fourthyear empathy scores showed a normal distribution according to the Shapiro-Wilk Test $(p>.05)$. In contrast, their empathy scores in the second year did not show a normal distribution. However, it was accepted to have a normal distribution since the kurtosis and skewness coefficients of their empathy scores in the second year were within the range of -1 to +1 (kurtosis=.299; skewness=-.885) (Can, 2013). According to the Mauchly Sphericity test, which was conducted to determine whether the homogeneity assumption was achieved or not, it was seen that the empathy scores of the participants did not meet the sphericity assumption $(p<.05)$. When the sphericity assumption is not provided, it is necessary to decide whether the difference is significant with the corrections to be made in F statistics according to the epsilon value. In general, it is suggested that Huynh-Feldt epsilon value be used when epsilon values are more significant than .75 (Can, 2013; Leech et al., 2005; Şencan, 2005). 
While analyzing the data collected to determine whether psychological counselor candidates' personal meaning profiles changed during their four-year undergraduate studies, One Way Anova for repeated measures was utilized. To perform One Way Anova for repeated measurements, it is necessary to examine the assumptions of normality and sphericity (Can, 2013). For the assumption of normality, the ShapiroWilk test was used because the number of participants was fewer than 50 . The results of the Shapiro-Wilk test revealed that the achievement, relationship, religion, and intimacy dimensions of the personal meaning profiles of the candidates did not have a normal distribution $(p<.05)$ in their first, second, third, and fourth years, whereas a normal distribution was observed in terms of self-acceptance dimension ( $p>.05)$. According to the Mauchly Sphericity Test, which was used to determine whether the sphericity assumption was achieved or not, the self-acceptance scores of the participants met the assumption of sphericity, too ( $p>.05)$.

The first, second, and fourth-grade self-transcendence scores of the psychological counselor candidates showed normal distribution according to the Shapiro Wilk test $(p>.05)$. In contrast, the third-grade self-transcendence scores did not show normal distribution. However, the third-year self-transcendence scores were accepted to have a normal distribution since their kurtosis and skewness coefficients were within the range of -1 to +1 (kurtosis $=.888$; skewness $=-.084)($ Can, 2013). Considering the results of the Mauchly Sphericity Test, which was done to determine whether the homogeneity assumption was met or not, it can be said that the selftranscendence scores of psychological counselor candidates met the assumption of sphericity ( $p>.05)$.

Psychological counselor candidates' first-year, second-year, and third-year perceived-justice scores were observed to have a normal distribution according to the Shapiro-Wilk Test $(p>.05)$; however, those scores did not show a normal distribution in the fourth year. However, the fourth-year perceived justice scores were accepted to have a normal distribution since their kurtosis and skewness coefficients were within the range of -1 to +1 (kurtosis $=.043$; skewness $=-.812)$ (Can, 2013). Based on the results of the Mauchly Sphericity Test, which was conducted to determine whether the sphericity assumption was met or not, it can be said that the perceived justice scores of psychological counselor candidates met the assumption of sphericity $(p>.05)$.

The Friedman Test, one of the non-parametric tests, was applied in this study because the normality assumptions of the achievement, relationship, religion, and intimacy dimensions of the personal meaning profile scale were not met. On the other hand, One Way Anova for repeated measures, which is among parametric tests, was also applied since normality assumptions of the self-transcendence, self-acceptance, and perceived justice dimensions were met. The data were analyzed with SPSS 22 package program.

\section{Ethical Procedures}

The study was designed in accordance with ethical principles and rules. Ethics committee document numbered 61923333/050.99 of the study was given by Sakarya University Social and Human Sciences Ethics Committee. 


\section{Results}

The results of the One Way Anova for repeated measures aiming at revealing whether psychological counselor candidates' empathy-related scores show a significant difference according to their grade level (year-by-year) are given in Table 1.

Table 1

The Results of One Way Anova with Repeated Measures Aiming at Revealing Whether Psychological Counselor Candidates' Empathy-Related Scores Show A Significant Difference according to Their Grade Level (year-by-year)

\begin{tabular}{cccccccccc}
\hline Grades & $n$ & $\bar{X}$ & $s d$ & & $\begin{array}{c}\text { Sum-of- } \\
\text { Squares }\end{array}$ & df & $\begin{array}{c}\text { Mean of } \\
\text { Squares }\end{array}$ & $F$ & $p$ \\
\hline 1 & 36 & 76.69 & 7.76 & Between Groups & 5646.58 & 35 & 161.33 & & \\
2 & 36 & 75.50 & 8.70 & Factor & 74.91 & 2.53 & 29.55 & & \\
3 & 36 & 77.53 & 7.45 & Error & 3091.34 & 88.72 & 34.84 & .85 & .45 \\
4 & 36 & 76.64 & 7.63 & Total & 8812.83 & & & & \\
\hline
\end{tabular}

According to Table 1, the empathy levels of psychological counselor candidates do not differ significantly based on their grade level $(p>.05)$. This finding shows that the empathy levels of psychological counselor candidates did not change throughout their undergraduate studies.

The results of the Friedman analysis, which was conducted to reveal whether the participants' scores related to the religion dimension of the personal meaning scale changed throughout their undergraduate studies, are given in Table 2.

Table 2

The Results of the Friedman Analysis Aiming at Revealing Whether Psychological Counselor Candidates' Religion-Related Scores Changed throughout Their Undergraduate Studies

\begin{tabular}{cccccc}
\hline Grade & $n$ & Mean Rank & $d f$ & Chi-Square & $p$ \\
\hline 1 & 36 & 3.25 & & & \\
2 & 36 & 2.54 & 3 & 22.741 & .000 \\
3 & 36 & 2.33 & & & \\
4 & 36 & 1.88 & & & \\
\hline
\end{tabular}

According to Table 2, it can be said that psychological counselor candidates' scores related to the religion dimension of the personal meaning scale showed a significant difference during their undergraduate studies $(p<.05)$. To understand between which grade levels this difference happened, Bonferonni correction was made and interpreted. Their first-year scores of the religion sub-dimension of the personal meaning profile scale are statistically higher than their third and fourth-grade scores. The analysis also showed that psychological counselor candidates had the highest score for the religion dimension of the personal meaning profile scale in the first year while 
they had the lowest score for the same dimension in the fourth year. In addition, the effect size calculation was made to reveal the effect of the change. As the effect size statistics of the Friedman test, Kendall's W value can be used (Green \& Salkind, 2014). The Kendall $\mathrm{W}$ value, related to the change in the scores of the religion dimension of the personal meaning profile scale of the psychological counselor candidates during their undergraduate education, was calculated as .211 . This value shows that the change that occurs during education is very low.

The results of the Friedman analysis, which was conducted to examine whether the participants' scores related to the intimacy dimension of the personal meaning scale changed throughout their undergraduate studies, are given in Table 3.

Table 3

The Results of the Friedman Analysis Aiming to Reveal Whether Psychological Counselor Candidates' Intimacy-Related Scores Changed throughout Their Undergraduate Studies

\begin{tabular}{cccccc}
\hline Grade & $n$ & Mean Rank & $d f$ & Chi-Square & $p$ \\
\hline 1 & 36 & 2.52 & & & \\
2 & 36 & 2.63 & 3 & 10.653 & .014 \\
3 & 36 & 2.63 & & & \\
4 & 36 & 1.93 & & & \\
\hline
\end{tabular}

Considering the findings given in Table 3, it can be concluded that the participants' scores related to the intimacy dimension of the personal meaning profile scale showed a significant difference during their undergraduate studies $(p<.05)$. To understand between which grade levels this difference happened, Bonferonni correction was made and interpreted. The scores for the intimacy dimension of the personal meaning profile scale of the participants in their first year were statistically higher than their scores in the fourth grade. The analysis also demonstrated that the participants had the highest score for the intimacy dimension of the personal meaning profile scale in their first year, while they got the lowest score in the fourth year. In addition, the effect size calculation was made to reveal the effect of the change. As the effect size statistics of the Friedman test, Kendall's W value can be used (Green \& Salkind, 2014). The Kendall $\mathrm{W}$ value, related to the change in the scores of the intimacy dimension of the personal meaning profile scale of the psychological counselor candidates during their undergraduate education, was calculated as .099. This value shows that the change that occurs during education is very low.

Furthermore, Friedman's analysis indicated that the participants' scores related to the achievement and relationship dimensions of the personal meaning profile scale did not change significantly during their undergraduate studies $(p>.05)$. Finally, the One Way Anova for repeated measures suggested that there was no significant difference in their scores regarding the self-acceptance, self-transcendence, and perceived justice dimensions of the personal meaning profile scale of the participants during their academic studies at university $(p>.05)$. 


\section{Discussion and Conclusion}

The main subject of this research is whether empathy as a concept identified with the field of guidance and psychological counseling is a feature acquired by students in their undergraduate studies. The study results indicated that the empathy levels of psychological counselor candidates did not change during their four-year undergraduate studies. Karataş (2012), in his research involving university students, has found that the highest level of empathy skill was among fourth graders. It is possible to come across studies indicating that empathic tendency and empathic skill scores of guidance and psychological counseling program students are higher than the scores of students in different programs (Ekinci, 2009; Karataş, 2012; Yavuz-Güler \& İşmenGazioğlu, 2008). However, there is no evidence proving that their empathy levels change over the years depending on their education.

In the literature, it is possible to find studies which indicate that training to develop empathy skills can help psychological counselors (İkiz \& Karaca, 2011; Sargin, 1993) and nursing students (Karaca et al., 2013) to develop their empathy skills. Furthermore, the studies conducted by Karaca et al. (2013) and Sargin (1993) examined the empathic tendencies of the participants, and it was seen that the training provided to the participants did not change their empathic tendencies (Karaca et al., 2013; Sargin, 1993). In these studies, empathic tendencies and empathic skills were treated as two different concepts (Karaca et al., 2013; Sarg1n, 1993). While the tendency is mostly used to express an internal situation, skill indicates the unleashing of a potential through practice and learning (Budak, 2003). Since the basic empathy scale used in the current research (Topcu et al., 2010) is mainly intended to measure the empathy tendencies of individuals, it can be considered that there is no change in the empathy levels of the candidates during the undergraduate education.

In a cross-sectional study conducted with 171 college students studying in psychological counseling and guidance, Alver (2005) used the Empathic Skills Scale developed by Dökmen (1988). In Alver's study (2005), the second, third, and fourthgraders' empathy skill levels were found to be significantly higher than those of first graders. Another cross-sectional study carried out by Ünal in 1997 also showed that students studying psychological counseling and guidance program students' empathic tendency levels are low in the first year of their education. Taking both studies (Alver, 2005; Ünal, 1997) into consideration, the distinctive features of this current study were that it was a longitudinal study in which measurements were made with the same participants at intervals of one year, that psychological counselor candidates' empathy levels were not observed to develop during their undergraduate studies, that a different tool was used for empathy level measurements, and that personal meaning profiles of the participants were also examined besides their empathy levels.

Some inexperienced psychological counselors fail to empathize with a client properly because they feel too intertwined due to their willingness to help (Hackney \& Cormier, 2015). Uslu (2005) stated in his study that it is found that some psychological counselors see themselves as inadequate in terms of their psychological listening skills, including empathy. Uslu's (2005) study supports the finding that researchers did not change their empathy scores during their undergraduate education. This conclusion raises whether there are sufficient educational and experiential opportunities provided to psychological counseling and guidance students and the counselors to improve their 
empathy levels. In an experimental study, Schomaker (2013) found that mindfulness training resulted in an increase in mindfulness, empathy, and therapeutic alliance scores of counselor trainees doing clinical practice. Similarly, Leppma (2011) found that mindfulness-based loving-kindness meditation improved the cognitive empathy levels of psychological counselors. These studies done by Schomaker (2013) and Leppma (2011) suggest that experiential training based on different approaches can contribute to the psychological counselors' training. It can be said that integrating the advancements in the field of mental health into the programs in institutions providing education in the field of psychological counseling and guidance constitutes a critical point.

Another result of the research: The psychological counselor candidates' the religion dimension of the personal meaning profile scale had the highest score in the first grade and the lowest score in the fourth grade. King et al. (2012) have conducted supportive studies that empathy connects spiritual and emotional intelligence to each other. Therefore, empathy can be said to interact with spiritual life. Uysal (2016) examined the relationship between religiosity variables and empathic tendencies among young people with an age range of 14-26, found that the higher the level of religiosity got, the better empathic skills became. In the present study, the fact that the fourth-grade psychological counselor candidates were lower than the first-grade religion scores and that their empathy levels did not develop throughout their undergraduate education included the points that overlap with the findings of Uysal. It can be thought that in the first years of university, students are trying to find meaning in the values they have brought from their families. One of these values includes the religious dimension. However, in a sense, the young person trying to discover himself/herself may have developed the ability to find meaning in different ways at the end of his university years. This may have led to a decrease in the level of finding meaning in religion in the fourth year.

Morrison and Borgen (2010) presented a study on the impact of psychological counselors' Christian spiritual and religious beliefs on the counseling process. In this study, it was observed that for some counselors, the idea that God brought the client and the counselor together strengthened their relationship, that the counselor formed a way to connect to God, and that some tried to integrate Jesus' empathetic approach into counseling processes. The current research was conducted in Turkish society. Karairmak (2008) defines Turkey as a country that consists of sub-groups and subcultures emerging from social class differences, religious beliefs, traditions, geographic location, and family structure. These rich diversity sources in Turkish society may be considered an obstacle to benefiting from the sources of religion during the counseling process. The place of religion in psychological counseling processes will be a topic of discussion (Abanoz, 2020; Dilmaç et al., 2016). However, considering the human characteristics of the psychological counselors, it can be suggested that how religion affects counseling process in the Turkish community be studied, as well.

According to the study, the psychological counselors had the highest score for the intimacy dimension of the personal meaning profile scale in their first year, while they got the lowest score for the same in their fourth year. Having a shared, pre-existing hermeneutical structure, intimate relationships differ from non-intimate relationships (Kirk, 2007). For intimacy to develop, people need to introduce something. When people choose intimacy with others, they can reduce the inherited existential isolation 
(Jurica et al., 2014). The importance of intimacy, which people use to find meaning, for psychological counselors is seen in Ateş's (2016) study. According to Ateş (2016), the social support of psychological counselor candidates, the relationships they establish with relatives in a context positively affect their well-being.

Although there is no significant difference in the averages, when we consider the decrease of approximately one point in the participants' scores in their fourth year, as the psychological counselor candidates are nearing the end of the undergraduate education process, it can be thought that the psychological counselor candidates are distanced from intimacy relations by using suppression and emotional isolation (Blackman, 2014) mechanisms which are the primary defense mechanisms used by adults. Although Turkey is often regarded as a community culture, it also shows individualistic characteristics, especially in areas where urbanization is intense. Kağıtçıbaşı (2008) addressed these characteristics under the title of 'autonomousrelational self' and stated that individuals are autonomous in making decisions and being effective, but still connected to the society through values. The vast majority of students who step into university life are separated from their families for the first time and get into an individualistic existence process. It can be thought that they continued the traditional techniques they brought from their families in the first year of their university life. However, in the last years, there was a decrease in the situation of finding meaning in intimacy with individualization.

The study's findings indicate that there was no significant difference in the participants' scores regarding the achievement, relationship, self-acceptance, selftranscendence, and perceived justice dimensions of the personal meaning profile scale during their academic studies. No similar findings were found in the literature. It may be the subject of another study to investigate which variables shape these dimensions, which influence the way individuals find meaning in their lives.

\section{Conclusion and Suggestions}

All in all, contrary to common belief, empathy, which is a skill directly associated with being a psychological counselor, has not changed undergraduate education. A similar study to be conducted with psychological counselor candidates studying at other universities could contribute to the results of this study.

The empathy skills and empathy tendencies of psychological counseling and guidance students with a longitudinal study may be suggested to make a comparison by measuring.

It may be suggested that a cross-sectional and longitudinal study can be conducted using the same tool to measure the empathy levels of psychological counselor candidates to examine the development in their empathy levels during their undergraduate studies.

According to the result of the research, it can be said that the training aimed at improving the empathy levels of the psychological counselor candidates should be made more functional. It can be suggested to enrich the content of psychological counselor candidates to gain empathy skills in both theoretical and practical courses during their undergraduate education. Training can be organized within the Psychological Counseling and Guidance Association. 
In addition, the reasons why psychological counselor candidates' search for personal meaning in religion and intimacy is at the highest level at the beginning of undergraduate education but at the lowest level at the end of undergraduate education can be investigated. During undergraduate education, studies that support the search for personal meaning can be planned.

\section{Statement of Responsibility}

All of the authors contributed to the study equally.

\section{Conflicts of Interest}

There are no conflicts of interest in this study. 


\section{References}

Abanoz, S. (2020). Türkiye'de yapılan 'dinî başa çıkma' konulu araştırmalar hakkında bir değerlendirme [An evaluation of research on 'religious coping' in Turkey]. Eskiyeni, 40, 406-429. https://doi.org/10.37697/eskiyeni.673386

Akın, A., Düşünceli, B., \& Çolak, T. S. (2016). Kişisel anlam profili: Geçerlik ve güvenirlik çalışması study [Personal meaning profile: Validity and reliability]. Ĕ̆itim Kuram ve Uygulama Araştırmaları Dergisi, 2(2), 12-29.

Alver, B. (2005). Psikolojik danışma ve rehberlik eğitimi alan öğrencilerin empatik beceri ve karar verme stratejilerinin çeşitli değişkenlere göre incelenmesi [The empathic skills and decision-making strategies of the students of the department of guidance and psychological counseling, faculty of education were studied]. Muğla Üniversitesi Sosyal ve Beşeri Bilimler Araştırmaları Dergisi, 14, 19-34.

Ateş, B. (2016). Perceived social support and assertiveness as a predictor of candidates psychological counselors' psychological well-being. International Education Studies, 9(5), 28-39. https://doi.org/10.5539/ies.v9n5p28 96-3319

Batthyany, A., \& Russo-Netzer, P. (2014). Psychologies of meaning. In Batthyany, A. \& Russo-Netzer, P. (Eds.), Meaning in positive and existential psychology (pp.324). Springer.

Blackman, J. S. (2014). Zihnin kendini koruma yollart: 101 savunma. Psikoterapi Enstitüsü Eğitim Yayınları.

Budak, S. (2003). Psikoloji sözlüğ̈̈̈. Bilim ve Sanat Yayınları.

Can, A. (2013). SPPS ile bilimsel araştırma sürecinde nicel veri analizi. Pegem Akademi.

Combs, A. W. (1986). What makes a good helper? A person-centered approach. Person-Centered Review, 1(1), 51-61.

Damiano, R. F., de Andrade Ribeiro, L. M., dos Santos, A. G., da Silva, B. A., \& Lucchetti, G. (2017). Empathy is associated with meaning of life and mental health treatment but not religiosity among Brazilian medical students. Journal of Religion and Health, 56, 1003-1017. https://doi.org/10.1007/s10943-016-0321-9

Degges-White, S., \& Stoltz, K. (2015). Archetypal identity development, meaning in life, and life satisfaction: differences among clinical mental health counselors, school counselors, and counselor educators. Adultspan Journal, 14(1), 49-61. https://doi.org/10.1002/j.2161-0029.2015.00036.x

Dilmaç, B., Ekşi, F., \& Şimşir, Z. (2016). Psikolojik danışma deneyimi yaşayanların dini başa çıkma, psikolojik iyi olma ve affetme düzeyleri arasindaki yordayıcı ilişkiler: Bir model önerisi [The predictive relationship among the levels of religious coping, psychological well-being, and forgiveness for those undergoing psychological counseling: An example model]. Presented at First International Congress on Religious-Spiritual Counselling on 7-10 April 2016, Istanbul.

Dökmen, Ü. (1988). Empatinin yeni bir modele dayandırılarak ölçülmesi ve psikodrama ile geliştirilmesi. Ankara Üniversitesi Eğitim Bilimleri Fakültesi Dergisi, 21(1), 155-190.

Dökmen, Ü. (2006). Illetişim çatışmaları ve empati. Sistem Yayıncılık. 
Egan, G. (2011). The skilled helper (Ö. Yüksel, Trans.). Kaknüs Yayınc1lık.

Ekinci, Ö. (2009). Öğretmen adaylarının empatik ve eleştirel düşünme eğilimlerinin incelenmesi (Unpublished master's thesis). Çukurova Üniversitesi.

Erdur-Baker, Ö. (2016). Psikolojik danışma ve kültürel faktörler [Counseling psychology and cultural factors]. Türk Psikolojik Danışma ve Rehberlik Dergisi, 27(3), 109-122.

Eryılmaz, A., \& Mutlu Süral, T. (2014). Kuramdan uygulamaya bireyle psikolojik danışma, Anı Yayıncılık.

Fraenkel, J. R., \& Wallen, N. E. (2006). How to design and evaluate research in education. Mac Graw Hill Inc.

Frankl, V. (1999). Duyulmayan anlam çığlı̆̆ı (S. Budak, Trans.). (4 $4^{\text {th }}$ edition). Öteki Psikoloji Dizisi.

Frankl, V. (2007). Insanın anlam arayışı (S. Budak, Trans.). ( $8^{\text {th }}$ edition). Öteki Psikoloji Dizisi.

Gladstein, G. A. (1983). Understanding empathy: Integrating counseling, developmental, and social psychology perspectives. Journal of Counseling Psychology, 30(4), 467-482. https://doi.org/10.1037/0022-0167.30.4.467

Green, S. B., \& Salkind, N. J. (2014). Using Spss for Windows and Macintosh: analyzing and understanding data. Pearson.

Hackney, H., \& Cormier, S. (2008). Professional counselor: a process guide to helping (T. Ergene, \& S. Aydemir-Sevim, Trans.). Mentis Yayıncılık.

Hackney, H., \& Cormier, S. (2015). Counseling strategies and interventions (S. Doğan, \& B. Yaka, Trans. Eds.), Pegem Akademi.

İkiz, F. E., \& Karaca, R. (2011). Danışma becerileri eğitiminin psikolojik danışmanların empatik becerilerine etkisi [The effects of counseling skills education on empathic skills of counselors]. e-Journal of New World Sciences Academy, 6(2), 1585-1595.

Jolliffe, D., \& Farrington, D. P. (2006). Development and validation of the basic empathy scale. Journal of Adolescence, 29, 589-611. https://doi.org/10.1016/j.adolescence.2005.08.010

Jurica, J., Barenz, J., Shim, Y., Graham, K., \& Steger, M. F. (2014). Ultimate concerns from existential and positive psychological perspectives. In A. Batthyany and P. Russo-Netzer (Eds.), Meaning in positive and existential psychology (pp., 115-128). Springer.

Kağıtçıbaş1, Ç. (2008). Günümüzde insan ve insanlar: Sosyal psikolojiye giriş $\left(11^{\text {th }}\right.$ edition). Evrim Yayınevi.

Karaca, A., Açıkgöz, F., \& Akkuş, D. (2013). Eğitim ile empatik beceri ve empatik eğilim geliştirilebir mi?: bir sağlık yüksekokulu örneği. Acıbadem Üniversitesi Să̆lık Bilimleri Dergisi, 4(3), 118-122.

Karaırmak, Ö. (2008). Çok kültürlülük, kültürel duyarlılık ve psikolojik danışma [Multiculturalism, cultural sensitivity and counseling]. Türk Psikolojik Danışma ve Rehberlik Dergisi, 3(29), 115-129.

Karataş, Z. (2012). Eğitim fakültesi öğrencilerinin empatik becerileri ve benlik saygısı düzeylerinin incelenmesi [An investigation of self esteem levels and empathic skills 
of educational faculty students]. Mehmet Akif Ersoy Üniversitesi Eğitim Fakültesi Dergisi, 23, 97-114.

King, D. B., Mara, C. A., \& DeCicco, T. L. (2012). Connecting the spiritual and emotional intelligences: Confirming an intelligence criterion and assessing the role of empathy. International Journal of Transpersonal Studies, 31(1), 11-20. https://doi.org/10.24972/ijts.2012.31.1.11

Kirk, T. W. (2007). Beyond empathy: Clinical intimacy in nursing practice. Nursing Philosophy, 8, 233-243. https://doi.org/10.1111/j.1466-769X.2007.00318.x

Kurtyllmaz, Y. (2015). Counselor trainees' views on their forthcoming experiences in practicum course. Eurasian Journal of Educational Research, 61, 155-180. https://doi.org/10.14689/ejer.2015.61.9

Lawson, G. (2007). Counselor wellness and impairment: A national survey. Journal of Humanistic Counseling. Education and Development, 46, 20-34. https://doi.org/10.1002/j.2161-1939.2007.tb00023.x

Leech, N. L., Barret, K. C., \& Morgan, G. A. (2005). SPSS for Intermediate Statistics, Use and Interpretation. Lawrence Erlbaum Associates Inc.

Leppma, M. (2011). The effect of loving-kindness meditation on empathy, perceived social support, and problem-solving appraisal in counseling students (Unpublished doctoral dissertation). University of Central Florida.

Mcdonald, M. J., Wong, P. T. P., \& Gingras, D. T. (2012). Meaning in life measures and development of a brief version of the personal meaning profile. In Wong P. T. P., \& Fry, P. S. (Eds.), The human quest for meaning: A handbook of psychological research and clinical applications (pp.357-382). Routledge.

Morrison, M., \& Borgen, W. A. (2010). How Christian spiritual and religious beliefs help and hinder counselors' empathy toward clients. Counseling and Values, 55, 25-45. https://doi.org/10.1002/j.2161-007X.2010.tb00020.x

Nelson-Jones, R. (2015). Basic counselling skills, a helper's manual (G. Sart, Trans.). Nobel Akademi Yayıncılık.

Rogers, C. (1957). The necessary and sufficient conditions of therapeutic personality change. Journal of Consulting Psychology, 21, 95-103.

Sackett, C., Lawson, G., \& Burge, P. L. (2012). Meaningful experiences in the counseling process. The Professional Counselor, 2(3), 208-225. https://doi.org/10.15241/css.2.3.208

Sargın, N. (1993). Rehber öğretmenlerin empati düzeylerinin geliştirilmesine ilişkin bir model önerisi (Unpublished master's thesis). Dokuz Eylül Üniversitesi.

Sayar, K. (2011). Terapi, kültürel bir eleştiri. Timaş Yayınları.

Schomaker, S. A. (2013). The impact of mindfulness training on therapeutic alliance, empathy, and lived experience: A mixed methods study with counselor trainees (Unpublished doctoral dissertation). Texas A and M University.

Skovholt, T. M., \& Trotter-Mathison, M. (2011). The resilient practitioner: Burnout prevention and self-care strategies for counselors, therapists, teachers, and health professionals. ( $2^{\text {nd }}$ edition). Routledge/Taylor and Francis Group.

Şencan, H. (2005). Sosyal ve davranışsal ölçümlerde güvenirlik ve geçerlilik (1 ${ }^{\text {st }}$ edition). Seçkin Yayıncılık. 
Topcu, Ç., Baker, Ö. E., \& Çapa-Aydın, Y. (2010). Temel empati ölçeği türkçe uyarlaması: Geçerlik ve güvenirlik çalışması [Turkish adaptation of basic empathy scale: Validity and reliability study]. Türk Psikolojik Danışma ve Rehberlik Dergisi, 4(34), 174-182.

Uslu, M. (2005). Psikolojik danışmanların danışma becerilerinin geliştirilmesi (Unpublished master's thesis). Selçuk Üniversitesi.

Uysal, V. (2016). Gençlerde empati eğilimi, anne-baba tutumları ve dindarlık [Empathic tendency of young people, attitude of parents and religiosity]. Journal of The Faculty of Divinity of Dokuz Eylül University, Psychology of Religion Special Issue, 7-40.

Ünal, G. (1997). Psikolojik danışmanlık ve rehberlik ĕgitimi alan öğrencilerin empatik

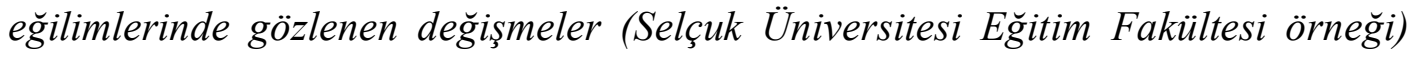
(Unpublished master's thesis). Selçuk Üniversitesi.

Voltan-Acar, N. (2015). Yeniden terapötik iletişim. Nobel Yayın Dağıtım.

Wong, P. T. P. (1998). Implicit theories of meaningful life and the development of the Personal Meaning Profile (PMP). In Wong P.T.P., \& Fry P.S. (Eds.), The human quest for meaning: A handbook of psychological research and clinical applications (pp. 111-140). Erlbaum.

Wong, P. T. P. (2012). Toward a dual-systems model of what makes life worth living. In Wong P.T.P., \& Fry P.S. (Eds.), The human quest for meaning: A handbook of psychological research and clinical applications (pp.3-22). Routledge.

Yavuz-Güler, Ç., \& İşmen-Gazioğlu, E. (2008). Rehberlik ve psikolojik danışmanlık öğrencilerinde öznel iyi olma hali, psikiyatrik belirtiler ve bazı kişilik özellikleri: karş1laştırmalı bir çalışma [Subjective well-being, psychiatric symptoms and some other characteristic properties among the students of guidance and psychological counselling]. Buca Faculty of Education Journal, 23, 107-114.

Yüksel, S. (2004). Empati eğitim programının ilköğretim öğrencilerinin empatik becerilerine etkisi. Uludă̆ Üniversitesi Ĕ̆itim Fakültesi, 7(2), 341-354. 